\title{
PENGARUH TINGKAT PENDIDIKAN, TINGKAT KESEHATAN, DAN PENGANGGURAN TERBUKA TERHADAP TINGKAT KEMISKINAN DI PROVINSI BALI
}

\author{
Ni Luh Made Ariasih ${ }^{1}$, Ni Nyoman Yuliarmi ${ }^{2}$ \\ Universitas Udayana, Bali ${ }^{1,2}$ \\ ariasih08@gmail.com ${ }^{1}$,nyuliarmi@unud.ac.id ${ }^{2}$
}

Received: 29-06-2021

Revised : 20-07-2021

Accepted: 25-07-2021

\begin{abstract}
Abstrak
Latar Belakang: Tingkat kemiskinan yang ada di Provinsi Bali terjadi dikarenakan adanya kesenjangan dan belum meratanya proses pembangunan ekonomi.

Tujuan: Penelitian dilakukan untuk menganalisa secara simultan dan parsial tingkat pendidikan, tingkat kesehatan, serta tingkat pengangguran terbuka terhadap tingkat kemiskinan. Serta untuk menganalisa variabel bebas yang berpengaruh secara dominan terhadap tingkat kemiskinan

Metode: Riset ini memakai jenis riset kuantitatif dengan pendekatan asosiatif.

Hasil: Hasil riset ini menyimpulkan bahwa secara simultan dan parsial tingkat pendidikan, serta pengangguran terbuka berpengaruh terhadap kemiskinan di Bali. Sementara itu, variabel tingkat kesehatan secara parsial berpengaruh negatif dan tidak signifikan terhadap kemiskinan di kabupaten/kota Provinsi Bali.

Kesimpulan: Variabel yang berpengaruh secara dominan terhadap tingkat kemiskinan, yaitu tingkat pendidikan.

Kata kunci: kemiskinan, bali; kesehatan; pengangguran terbuka; tingkat pendidikan.
\end{abstract}

\begin{abstract}
Background: The level of poverty in Bali Province occurs due to inequality and the uneven process of economic development.

Objective: The research was conducted to analyze simultaneously and partially the level of education, health level, and open unemployment rate to the poverty level. As well as to analyze the independent variables that have a dominant influence on the poverty level.

Methods: This research uses quantitative research with an associative approach.

Results: The results of this research conclude that simultaneously and partially the level of education, as well as open unemployment have an effect on poverty in Bali. Meanwhile, the health level variable partially has a negative and insignificant effect on poverty in the districts/cities of Bali Province.
\end{abstract}


Conslusion: The variable that has a dominant influence on the level of poverty is the level of education.

Keywords: poverty, bali; health; unemployment open; level of education.

\section{PENDAHULUAN}

Vicious circle of poverty atau teori dari lingkaran setan kemiskinan mengungkapkan negara yang sedang berkembang itu mengalami kemiskinan, dikarenakan adanya kegiatan produktivitas yang dinilai rendaah, sehingga menyebabkan pendapatan masyarakatnya yang rendah, dan mampu untuk memenuhi kebutuhan pangan yang minimum sebagai akibatnya modal masyarakat akan berkurang karena masyarakat yang tidak dapat menabung (Nurkse dalam (Kuncoro, 2004). Menurut (Manning \& Junankar, 1998) pada era pembangunan, warga miskin yang tidak bisa menyesuaikan keadaan dikatakan mengakibatkan pengangguran. Kemiskinan merupakan konsekuensi dari banyaknya jumlah penduduk dalam usia kerja yang menganggur, hal ini dapat terjadi diakibatkan oleh rendahnya pendidikan (Seran, 2017).

Pernyataan tersebut didukung oleh pendapat (Dariwardani, 2014) bahwa pendidikan tentunya berkaitan dengan fenomena kemiskinan, dimana secara general semakin tinggi pendidikan masyarakat maka fenomena kemiskinan akan semakin rendah. Namun lulusan pendidikan tinggi yang banyak menganggur menyebabkan masalah serius bagi negara (Lim, 2011). Pengangguran yang disebabkan oleh lulusan pendidikan tinggi berarti tidak memanfaatkan sumber daya manusianya dengan baik. Pemerintah bertanggung jawab untuk mengatasi masalah tersebut (Meidani, 2011). Ini dikarenakan system pendidikan diamati tidak sesuai dengan keterampilan dan pendidikan yang diperlukan di lapangan pekerjaan (Mahmood \& et al, 2014).

Pertumbuhan ekonomi dapat didorong oleh peningkatan produktivitas. Melalui peningkatan kualitas pendidikan akan mendorong peningkatan produktivitas dalam perekonomian secara menyeluruh yang mendorong peningkatan ekonomi masyarakat. Tingginya kualitas pendidikan masyarakat menimbulkan ide-ide kreatif baru yang memunculkan pengusaha-pengusaha kreatif dilihat melalui penciptaan UMKM baru yang senantiasa bermunculan. UMKM memiliki kemampuan penyerapan tenaga kerja yang besar (Yuta, Ropika, \& Suhartini, 2014). Meningkatnya UMKM maka akan terjadi kenaikan penyerapan dan kesempatan kerja yang tinggi. Secara berangsur-angsur akan memberikan dampak pada peningkatan pendapatan. Semakin lama sesorang mengenyam pendidikan semakin tinggi pendapatannya (Tisnawati \& Shabrina, 2014).

Fenomena ini akan mendorong proses kenaikan kesejahteraan masyarakat dan turunnya angka kemiskinan. Maka dari itu peluang kesempatan kerja yang terbuka bagi masyarakat miskin wajib diperhatikan dalam rangka mempertahankan daya beli sehingga setiap terjadi peningkatan pendapatan akan lebih berarti untuk mencukupi kebutuhan dasar atau dalam hal meningkatkan kualitas hidup (Sri Budhi, 2013). Oleh sebab itu perhatian terhadap kualitas pendidikan esensial dalam usaha pengentasan kemiskinan. Bali adalah salah satu provinsi yang mempunyai perekonomian dengan perkembangan yang sangat cepat, akan tetapi pada kondisi tersebut jumlah penduduk miskin nya masihlah sangat tinggi dan seringkali lebih banyak dijumpai pada daerah pedesaan. Hal ini menunjuk provinsi Bali harus memberikan perhatian yang khusus mengenai kemiskinan oleh pemerintah. Berikut merupakan tingkat kemiskinan pada tahun 2010 - 2019 yang dijelaskan pada Tabel 1 seperti dibawah ini. 
Tabel 1. Persentase Penduduk Miskin Menurut Kabupaten/Kota di Provinsi Bali Tahun 2010-2019

\begin{tabular}{|c|c|c|c|c|c|c|c|c|c|c|c|}
\hline $\begin{array}{l}\text { Kabupaten/ } \\
\text { Kota }\end{array}$ & 2010 & 2011 & 2012 & 2013 & 2014 & 2015 & 2016 & 2017 & 2018 & 2019 & $\begin{array}{c}\text { Rata- } \\
\text { rata }\end{array}$ \\
\hline Jembrana & 8.11 & 6.56 & 5.74 & 5.56 & 5.83 & 5.84 & 5.33 & 5.38 & 5.2 & 4.88 & 5.84 \\
\hline Tabanan & 6.96 & 5.62 & 4.9 & 5.21 & 5.61 & 5.52 & 5 & 4.92 & 4.46 & 4.21 & 5.24 \\
\hline Badung & 3.23 & 2.62 & 2.16 & 2.46 & 2.54 & 2.33 & 2.06 & 2.06 & 1.98 & 1.78 & 2.32 \\
\hline Gianyar & 6.68 & 5.4 & 4.69 & 4.27 & 4.57 & 4.61 & 4.44 & 4.46 & 4.19 & 3.88 & 4.71 \\
\hline Klungkung & 7.58 & 6.1 & 5.37 & 7.01 & 7.01 & 6.91 & 6.35 & 6.29 & 5.86 & 5.4 & 6.38 \\
\hline Bangli & 6.41 & 5.16 & 4.52 & 5.45 & 5.86 & 5.73 & 5.22 & 5.23 & 4.89 & 4.44 & 5.29 \\
\hline Karangasem & 7.95 & 6.43 & 5.63 & 6.88 & 7.3 & 7.44 & 6.61 & 6.55 & 6.28 & 6.25 & 6.73 \\
\hline Buleleng & 7.35 & 5.93 & 5.19 & 6.31 & 6.79 & 6.74 & 5.79 & 5.74 & 5.36 & 5.19 & 6.03 \\
\hline Denpasar & 2.21 & 1.79 & 1.52 & 2.07 & 2.21 & 2.39 & 2.15 & 2.27 & 2.24 & 2.1 & 2.09 \\
\hline Provinsi Bali & 5.67 & 4.59 & 3.95 & 4.49 & 4.76 & 4.74 & 4.25 & 4.25 & 4.01 & 3.79 & 5.84 \\
\hline
\end{tabular}

Source: (BPS, Provinsi Bali, 2020)

Pada Tabel 1 menurut informasi data yang diluncurkan oleh BPS Provinsi Bali, penduduk yang miskin persentasenya tahun ke tahun cenderung tidak adanya perubahan yang signifikan, standar hidup yang lebih baik pada kondisi masyarakat. Di samping itu, data juga menunjukan bahwa di Provinsi Bali terdapat perbedaan yang mencolok mengenai persentase penduduk miskin antar kabupaten/kota. Penyumbang kemiskinan terbesar jatuh kepada sektor pertanian (Wardhana, Ihle, \& Heijman, 2017). Hal ini mengindikasikan bahwa terdapat ketimpangan kesenjangan ekonomi regional/antar wilayah. Maka dari itu sangat diperlukan menaikan pertumbuhan ekonomi agar bisa mengurangi kemiskinan (Dollar \& Aart Kraay, 2002). Negara berkembang seperti Indonesia paling umum mempunyai masalah pada kemiskinan (Vincent, 2009). Menurut (Williamson, 2001) pemberantasan kemiskinan menjadi tujuan utama dari pembangunan manusia.

Tabel 2. Jumlah Penduduk Bali Berumur 15 Tahun ke atas yang termasuk Pengangguran Menurut Kabupaten/Kota dan Pendidikan Tertinggi yang ditamatkan

\begin{tabular}{|c|c|c|c|c|c|c|c|c|c|c|}
\hline $\begin{array}{c}\text { Kabupaten/ } \\
\text { Kota }\end{array}$ & $\begin{array}{c}\text { Tidak/Bel } \\
\text { um } \\
\text { Tamat } \\
\text { SD } \\
\end{array}$ & SD & $\begin{array}{c}\text { SM } \\
\mathbf{P}\end{array}$ & SMA & $\begin{array}{c}\text { SM } \\
\mathbf{K}\end{array}$ & $\begin{array}{c}\text { D. } \\
\text { I/II }\end{array}$ & D. III & $\begin{array}{c}\text { D. } \\
\text { IV/S1 }\end{array}$ & $\begin{array}{c}\mathbf{S} 2 / \mathrm{S} \\
\mathbf{3}\end{array}$ & $\underset{\mathbf{h}}{\text { Jumla }}$ \\
\hline Jembrana & 0 & 156 & 157 & 1231 & 143 & 177 & 0 & 177 & 0 & 2041 \\
\hline Tabanan & 216 & 151 & 0 & 1117 & 1110 & 168 & 0 & 724 & 0 & 3486 \\
\hline Badung & 0 & 0 & 0 & 438 & 239 & 196 & 565 & 0 & 0 & 1438 \\
\hline Gianyar & 0 & 365 & 153 & 1067 & 1861 & 175 & 252 & 440 & 0 & 4313 \\
\hline Klungkung & 171 & 324 & 125 & 652 & 175 & 0 & 97 & 89 & 0 & 1633 \\
\hline Bangli & 0 & 0 & 79 & 647 & 0 & 175 & 0 & 144 & 0 & 1045 \\
\hline Karangasem & 0 & 0 & 284 & 665 & 423 & 0 & 154 & 0 & 0 & 1526 \\
\hline Buleleng & 678 & 793 & 945 & 2994 & 3387 & 871 & 0 & 812 & 0 & 10480 \\
\hline Denpasar & 0 & 287 & 1344 & 1990 & 2095 & 1639 & 420 & 3814 & 0 & 11589 \\
\hline Jumlah & 1065 & 2076 & 3087 & $\begin{array}{c}1080 \\
1 \\
\end{array}$ & 9433 & 3401 & 1488 & 6200 & 0 & 37551 \\
\hline
\end{tabular}

Source: BPS Provinsi Bali, 2020

Tabel 2 Jika dilihat dari sisi tingkat pendidikan pada Provinsi Bali, sebagian besar masyarakat yang tidak bekerja berasal dari masyarakat yang pendidikan terakhirnya SMA/SMK dan Sarjana/Diploma IV. Ini mencerminkan bahwa jenjang pendidikan yang 
lebih tinggi, tidak menjamin bahwa semua penduduk memperoleh pekerjaan. Penduduk dengan tingginya jenjang pendidikan yang tidak bekerja/menganggur, tidak dapat menggambarkan kondisi kemiskinan yang sebenarnya. Karena pada dasarnya, pengangguran terdidik memilih menganggur karena belum menemukan pekerjaan yang sesuai dengan kompetisi yang didapatkan saat bersekolah atau sedang membantu usaha keluarga, sehingga tercatat tidak bekerja. Dan keluarga masih bisa mendukung kebutuhan hidup pengangguran terdidik. Sehingga, tingginya tingkat pendidikan tidak mencerminkan kondisi kemiskinan di Provinsi Bali. Pendiidikan tinggi yang diharapkan membrantas kemiskinan menjadi keliru, salah satu penyebab yang menjadikan bertambahkan pengangguran terdidik (Ewubare, Ogbuagu, \& Regina, 2017). Jika ditinjau dari rata rata harapan hidup saat lahir di Provinsi Bali cukup tinggi. Meskipun rata rata setiap tahun meningkat, namun tidak memperlihatkan pengaruh langsung terhadap penurunan tiingkat kemiiskinan. Begitu juga dengan taraf pengangguran terbuka di Provinsi Bali cenderung fluktuatif, yang rata rata mengarah pada penurunan, namun tingkat kemiskinan cenderung konstan/tidak ada perubahan baik penurunan ataupun peningkatan yang terlalu signifikan. Hal ini dapat terjadi karena antar kabupaten/kota rata rata persentase penduduk miskin yang bervariasi.

Riset ini bertujuan: 1) untuk mengetahui dan menganalisis pengaruh secara simultan dan parsial tingkat pendidikan $\left(\mathrm{X}_{1}\right)$, tingkat kesehatan $\left(\mathrm{X}_{2}\right)$, dan tingkat pengangguran terbuka $\left(\mathrm{X}_{3}\right)$ terhadap tingkat kemiskinan $(\mathrm{Y})$ di Kabupaten/Kota Provinsi Bali; 2) Untuk mengetahui dan menganalisis variabel yang berpengaruh dominan terhadap tingkat kemiskinan (Y) di Kabupaten/Kota Provinsi Bali.

Tingkat Pendidikan memiliki hubungan yang negatif dan signifikan. Riset dari Purnami dan Saskara (2016), menyimpulkan variabel pendidikan mempunyai hubungan yang negatif dan signifikan terhadap jumlah penduduk miskin kabupaten/kota di Provinsi Bali. Hasil riset ini didukung dari studi empiris peneliti seperti (Wahyu \& et, 2018) menerangkan hasil yang sama namun berlokasi di kab/kota Prov Jawa Timur. Teori Human Capital yaitu modal manusia yang ditemukan oleh (Becker, 1993), teori ini mengajarkan bahwa pendidikan bisa meningkatkan keahlian atau skill yang bisa meningkatkan produktivitas. Teori ini juga meyatakan apabila karyawan/pekerja mempunyai produktivitas yang baik, maka tingkat pendapatan yang diberikan dari perusahaan juga akan meningkat.

Terdapat teori lingkaran setan yang bisa mempengaruhi tingkat kemiskinan. Apabila tingkat pendidikan yang ditempuh rendah, bisa mempengaruhi produktivitas SDM yang rendah, dan mengakibatkan mendapatkan upah yang rendah pula, sehingga bisa menyebabkan meningkatnya tingkat kemiskinan. Maka dari itu, sangat penting pemerintah untuk mewajibkan biaya pendidikan minimal 20\% dari Anggaran Pendapatan dan Belanja Daerah (APBD), guna memperbaiki kualitas sumber daya manusianya, agar kedepannya bisa memutus tali lingkaran setan.

Tingkat kesehatan memiliki hubungan negatif dan signifikan terhadap kemiskinan. Kesehatan ialah sebuah aspek penting dalam mendukung kesuksesan pada pembangunan khususnya untuk menaikkan kesejahteraan sosial. Hal tersebut ditandai dengan angka harapan hidup atau AHH yaitu rerata hidup seseorang dalam setahun, sampai dengan tahun tertentu atau $\mathrm{x}$, dalam kondisi mortalitas yang ada di disekitarnya. (BPS 2020) Semakin tinggi AHH, maka semakin menampakan derajat kesehatan, peningkatan kehidupan dan kesejahteraan masyarakat di suatu wilayah.

Riset yang dilaksanakan Faisal (Faisal, 2013), menyimpulkan bahwa tingkat kesehatan berpengaruh terhadap kemiskinan dan tingkat produktivitas di Provinsi Kalimantan Barat. Namun riset yang dilakukakan oleh Wongdesmiwati, yang menyimpulkan bahwa variabel angka harapan hidup tidak signifikan berpengaruh terhadap warga miskin (Wongdesmiwati, 2009). Studi empiris lain (Fitri \& Kaluge, 2017) bahwa variabel biaya pemerintahan di sektor tingkat kesehatan berdampak positif dan 
tidak signifikan. Karena tidak sejalannya penambahan kesehatan warga dengan kuantitas kesempatan kerja baru.

Tingkat pengangguran terbuka memiliki hubungan positif dan signifikan terhadap tingkat kemiskinan, yang didukung oleh beberapa riset sebelumnya. Studi empiris dilakukan oleh (Adi \& Arka, 2018), (Malat \& Jeffrey , 2013), (Aristina, Kembar , \& Darsana, 2017), (Hu \& Giuliano, 2017), (Wirawan \& Arka, 2015), (Williams, 2008), (Yanthi \& Marheni, 2015), menyimpulkan bahwa pengangguran terbuka mempunyai hasil yang sama dengan penelitian ini yaitu mempengaruhi tingkat kemiskinan. Semakin bertambahnya pengangguran maka akan mengakibatkan adanya pertambahan penduduk yang tidak produktif, sehingga hal tersebut tidak dapat mencukupi keperluan kehidupannya, ketika keperluannya tidak tercukupi dapat mengakibatkan tergoncangnya stabilitas dalam politik negara, selain itu juga dapat mengakibatkan bertambahnya angka kejahatan (Azeng \& Thierry, 1991-2009). Hubungan antar variable pada riset ini ditunjukkan pada gambar kerangka konsep tersaji pada Gambar 1.

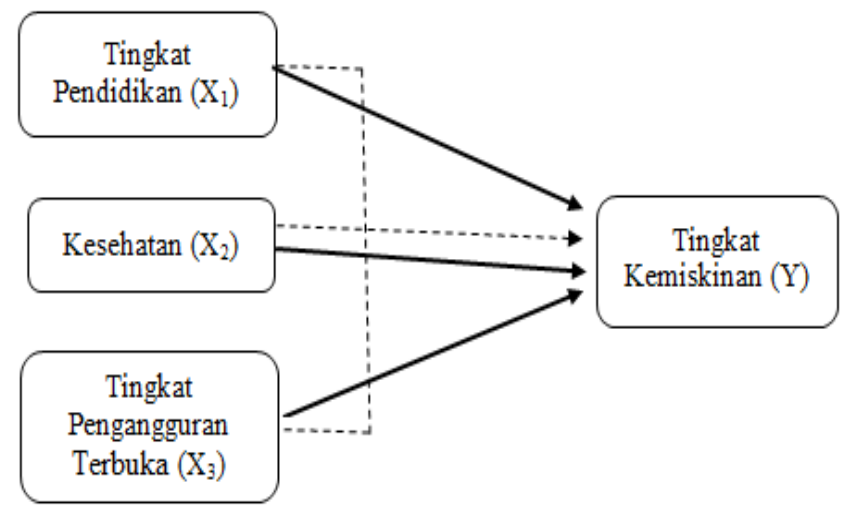

Gambar 1 Pengaruh Tingkat Pendidikan, Kesehatan, dan Pengangguran Terbuka terhadap Kemiskinan dalam Kerangka Konseptualnya

Berdasarkan kerangka konsep diatas, hipotesis penelitiannya dapat dijabarkan sebagai berikut: 1) Tingkat pendidikan $\left(X_{1}\right)$, tingkat kesehatan $\left(X_{2}\right)$, dan tingkat pengangguran terbuka $\left(\mathrm{X}_{3}\right)$ secara simultan berpengaruh terhadap tingkat kemiskinan $(\mathrm{Y})$; 2) Tingkat pendidikan $\left(X_{1}\right)$ secara parsial berpengaruh negatif terhadap tingkat kemiskinan $(\mathrm{Y})$; 3) Tingkat kesehatan $\left(\mathrm{X}_{2}\right)$ secara parsial berpengaruh negatif terhadap tingkat kemiskinan (Y); dan 4) Tingkat pengangguran terbuka $\left(\mathrm{X}_{3}\right)$ secara parsial berpengaruh positif terhadap tingkat kemiskinan (Y). Sudah banyak penelitian yang mengkaji mengenai tingkat kemiskinan, terutama di Provinsi Bali. Penelitian yang dilakukan oleh Ariasih et.al yang berjudul Pengaruh tingkat pendidikan, tingkat kesehatan, dan pengangguran terbuka terhadap tingkat kemiskinan di Provinsi Bali. Temuan dari penelitian ini yakni perlunya pemerintah daerah Provinsi Bali untuk mengalokasikan dana anggaran pendidikan minimum 20 persen dari total APBD dan APBN, terbukti dari persentase biaya pendidikan pada 2015 hingga 2019 rata rata berada dibawah 20 persen dari APBD Provinsi Bali. Rata rata hasil dari persentase biaya pendidikan dari tahun 2015-2019 di Kabupaten/Kota Provinsi Bali, terbilang belum sesuai dengan UUD 1945, Pasal 31 bag 4 mengenai biaya pendidikan minimum 20 persen dari total APBD dan APBN. Hal ini tentu saja dapat mempengaruhi sumber daya manusia (SDM), dan mengakibatkan produktivitas SDM menjadi turun kualitasnya. Akibat dari penurunan kualitas SDM bisa mengakibatkan meningkatnya pengangguran akibat dari rendahnya kualitas pendidikan. Hal ini bisa memicu meningkatnya tingkat kemiskinan di Provinsi Bali. 


\section{METODE PENELITIAN}

Riset ini memakai jenis riset kuantitatif dengan pendekatan asosiatif. Riset kuantitatif merupakan teknik riset yang didasari dengan falsafah posiitivisme guna untuk mengamati pada populasi/sampel yang telah ditetapkan, riset kuantitatif ini memiliki sasaran untuk melakukan pengujian hipotesa yang telah ditentukan (Sugiyono, 2013). Riset asosiatif mempunyai tujuan untuk mencari tahu pengaruh di antara variabel. Dalam riset ini pengertian operasional dari setiap variabel akan dijelaskan seperti dibawah ini: 1) Tingkat kemiskinan (Y), diperoleh dengan kriteria tertentu dari Badan Pusat Statistik Prov. Bali, tingkat kemiskinan dapat diukur melalui persentase penduduk miskin menurut kabupaten atau kota, berlaku pada 2010-2019 dengan satuan persentase; 2) Tingkat Pendidikan $\left(\mathrm{X}_{1}\right.$ adalah rerata lamanya sekolah di lokasi yang diteliti, tahun 2010-2019 dengan pengukuran skala rasio, dalam satuan tahun; 3) Tingkat kesehatan $\left(\mathrm{X}_{2}\right)$, diukur dengan menggunakan angka harapan hidup. AHH di Prov Bali, kurun waktu 2010-2019 diukur menggunakan satuan tahun, 4) Tingkat Pengangguran Terbuka $\left(X_{3}\right)$ ialah jumlah persentase pengangguran dengan kondisi seseorang termasuk pada angkatan kerja namun belum medapatkan suatu pekerjaan. Indikatornya yaitu Persentase Tingkatt Pengangguran Terbuka tahun 2010-2019 di kabupaten/kota Provinsi Bali, dengan pengukuran dalam satuan persen.

Riset ini memakai metode analisa dengan persamaan regresi linear berganda, guna mengetahui pengaruh variabel pendiidikan, kesehatan, serta pengangguran terbuka terhadap tingkat kemiskiinan. Menurut (Wirawan N. , 2017), persamaan regresi liner berganda bentuk umumnya seperti dibawah ini.

$$
Y=\alpha+\beta_{1} X_{1}+\beta_{2} X_{2}+\beta_{3} X_{3}+u \text {. }
$$

Ket: $\mathrm{Y}=$ Kemiskinan, $\mathrm{X}_{1}=$ Tingkat Pendidikan, $\mathrm{X}_{2}=$ Tingkat Kesehatan, $\mathrm{X}_{3}=$ Pengangguran terbuka, $\alpha=$ Intersept, $\beta=$ Koefisien regresi., $\mathrm{u}=$ Variabel pengganggu.

Menurut Widarjono (2009), data panel merupakan data yang di teliti selama kurun waktu yang ditentukan (time series) yang merupakan data individual (cross section). Time series gunanya melihat perubahan pada waktu yang ditentukan, sedangkan cross section untuk mencari tahu apakah adanya perbedaan diantara antar kabupaten atau kota. Estimasi dari regresi data panel mempunyai tiga pendekatan, bentuk yang sering dipakai pada regresi data panel yakni, bentuk random effect, bentuk fixed effect, serta bentuk common effect.

\section{HASIL DAN PEMBAHASAN}

\section{A. Hasil Penelitian}

\section{Persentase Biaya Pendidikan berdasarkan dibKabupaten/kota Provinsi Bali di Luar Transfer Daerah Tahun 2015-2019}

Biaya pendidikan Ialah suatu susunan yang direncanakan secara sistematis pada bentuk angka dan diinterpretasikan pada unit moneter dengan lokasi fungsi pendidikan yang disalurkan dengan lembaga atau kementerian negara mengalokasikan biaya pendidikan dengan dikirim ke wilayah dan pengeluaran pembiayaan. Lebih jelasnya berikut ini merupakan Gambar 2: 


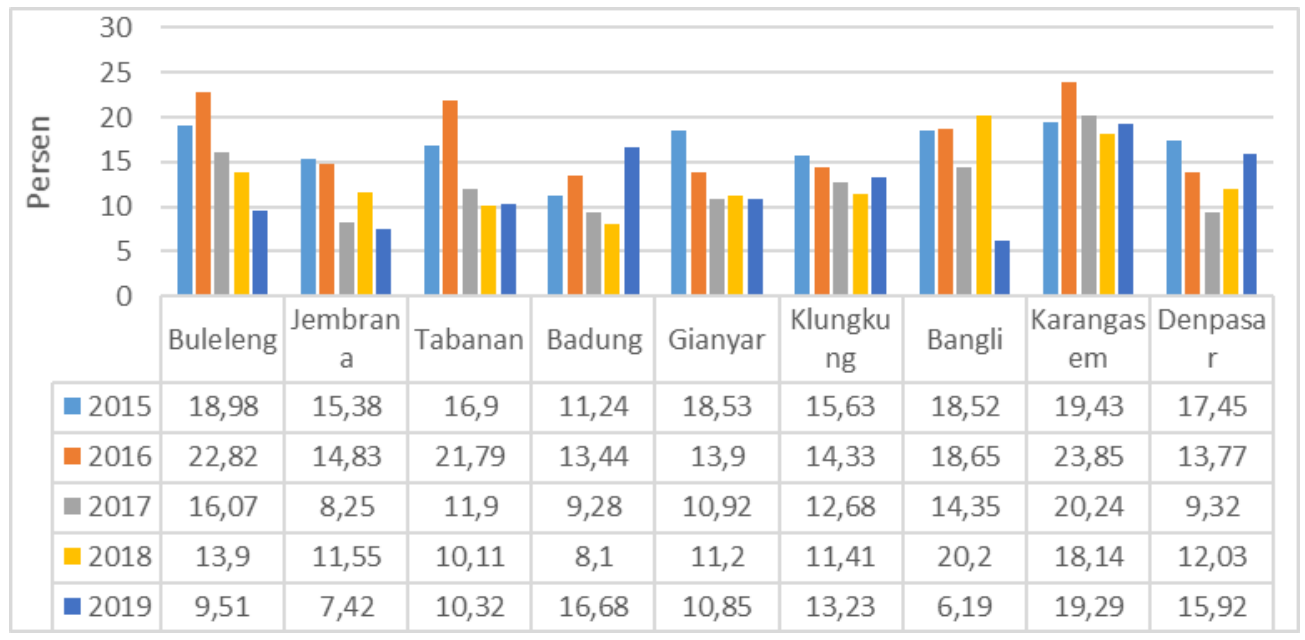

Sumber: Kemendikbud.go.id, Neraca Pendidikan Daerah 2019

Gambar 2 Persentase Anggaran Pendidikan Menurut Kabupaten/Kota Provinsi Bali di Luar Transfer Daerah Tahun 2015-2019

Gambar 2 dapat diamati bahwa persentase biaya pendidikan pada 2015 hingga 2019 rata rata berada dibawah 20 persen dari APBD Provinsi Bali. Biaya pendidikan mengalami fluktuasi, Rata rata hasil dari persentase biaya pendidikan dari tahun 2015-2019 di Kabupaten/Kota Provinsi Bali, terbilang belum sesuai dengan UUD 1945, Pasal 31 bag 4 mengenai biaya pendidikan minimum 20 persen dari total APBD dan APBN. Hal ini tentu saja dapat mempengaruhi sumber daya manusia (SDM), dan mengakibatkan produktivitas SDM menjadi turun kualitasnya. Sesuai dengan teori lingkaran setan apabila tingkat pendidikannya rendah, mempengaruhi produktivitas SDM rendah, dan mengakibatkan mendapatkan upah yang minim, sehingga dapat menyebabkan meningkatnya tingkat kemiskinan. Menurut (Shah, Shanzadi, \& Jean, 2012) apabila pendidikan meningkat, maka bisa meningkatkan pendapatan dan produktivitas. Maka dari itu, sangat penting pemerintah untuk mewajibkan biaya pendidikan minimal 20\% dari APBD, guna memperbaiki kualitas sumber daya manusianya, agar kedepannya bisa memutus tali lingkaran setan.

\section{Persentase Biaya Kesehatan terhadap APBD Provinsi Bali Tahun 2015-2019}

Biaya kesehatan merupakan susunan perencanaan sistematis dengan bentuk angka dalam unit moneter pada alokasi fungsi kesehatan. Asal biaya kesehatan bersumber dari pemerintahan, pemerintah, masyarakat, dan lainnya. Pemerintah wajib memenuhi hak hak kesehatan warga Negara, sesuai UU Kesehatan Nomor 36 Thn 2009 perihal kesehatan biaya kesehatan wilayah provinsi, kabupaten atau kota, mempunyai pengalokasian minimum 10\% dari APBD tidak termasuk dengan gaji atau pembelanjaan karyawan. Berikut merupakan persentase biaya kesehatan terhadap APBD Prov. Bali tahun 2015 sampai 2019. 


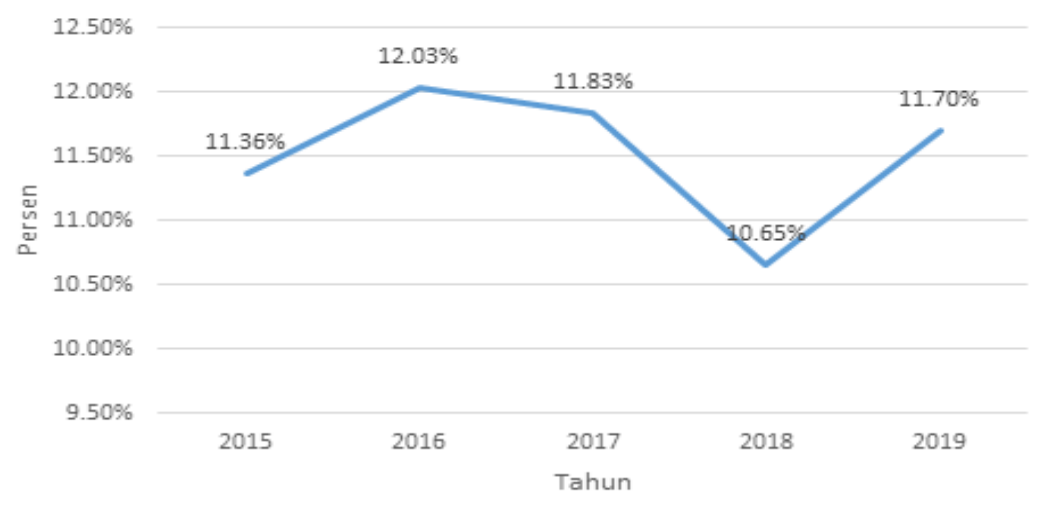

Source: Sunprog Diskes Prov. Bali, Bappeda Litbang Prov. Bali 2019

Gambar 3 Persentase Biaya Kesehatan Terhadap APBD Provinsi Bali Tahun 2015-2019

Gambar 3 Tahun 2015, Provinsi Bali memperoleh nilai $11.36 \%$, dan meningkat di tahun 2016 menjadi 12.03 persen. Namun pada 2017 terus menurun hingga tahun 2018 mendapat nilai $10.65 \%$, tetapi masih diatas biaya minimal yang ditetapkan oleh pemerintah. Pada tahun 2019 menunjukan peningkatan menjadi 11.70 persen. Dari data diatas dapat disimpulkan bahwa biaya kesehatan di Provinsi Bali sudah tergolong bagus dan diatas rata rata alokasi minimal. Apabila biaya kesehatan sudah tergolong baik, maka persentase masyarakatnya yang sehat juga tergolong tinggi. Sehingga bisa meningkatkan produktivitas dalam bekerja. Studi empiris yang dilakukan oleh Herry Faisal (2013), menyimpulkan bahwa tingkat kesehatan berpengaruh terhadap produktivitas dan kemiskinan di Provinsi Kalimantan Barat. Sedangkan, studi empiris yang dilakukan oleh Wongdesmiwati (2009) menyatakan bahwa variabel angka harapan hidup tidak signifikan berpengaruh terhadap penduduk miskin. Studi empiris lain dari Fithri dan Kaluge (2017) bahwa variabel pengeluaran pemerintah di sektor tingkat kesehatan memiliki dampak positif dan tidak signifikan.

\section{Perkembangan Upah Minimal Kabupaten atau Kota (UMK) Provinsi Bali} Tahun 2015-2019

UMK atau Upah minimum kabupaten/kota ialah gaji minimal yang sudah ditentukan oleh pemerintah provinsi. Penetapan upah ini didasari Perpres No 78 Tahun 2015. Pemerintah kota/kabupaten biasa menetapkan upah setiap setahun sekali. Upah minimum setiap kabupaten/kota biasanya berbeda-beda nominalnya, ini dikarenakan beberapa faktor yang menjadi penyebabnya. Salah satu faktornya yaitu Kebutuhan Layak Hidup yang melingkupi standar biaya hidup selama satu tahun dengan layak.

Tabel 3. Persentase Upah Minimum Kabupaten/Kota Provinsi Bali Tahun 2015-2019

\begin{tabular}{lccccc}
\hline Kabupaten/Kota & $\mathbf{2 0 1 5}$ & $\mathbf{2 0 1 6}$ & $\mathbf{2 0 1 7}$ & $\mathbf{2 0 1 8}$ & $\mathbf{2 0 1 9}$ \\
\hline Jembrana & $1,662,500$ & - & $2,006,617$ & $2,181,393$ & $2,356,559$ \\
Tabanan & $1,706,700$ & $1,902,970$ & $2,059,965$ & $2,239,500$ & $2,419,332$ \\
Badung & $1,905,000$ & $2,124,075$ & $2,299,311$ & $2,499,581$ & $2,700,297$ \\
Gianyar & $1,707,750$ & $1,904,141$ & $2,061,233$ & $2,240,766$ & $2,421,000$ \\
Klungkung & $1,650,000$ & $1,839,750$ & $1,991,529$ & $2,164,992$ & $2,338,840$
\end{tabular}




\begin{tabular}{llllll} 
Bangli & $1,622,000$ & $1,808,530$ & $1,957,734$ & $2,128,253$ & $2,299,152$ \\
Karangasem & $1,700,000$ & $1,895,500$ & $2,051,879$ & $2,180,000$ & $2,355,054$ \\
Buleleng & $1,650,000$ & $1,839,750$ & $1,991,529$ & $2,165,000$ & $2,338,850$ \\
Denpasar & $1,800,000$ & $2,007,000$ & $2,173,000$ & $2,363,000$ & $2,553,000$ \\
\hline Provinsi Bali & $1,621,172$ & $1,807,600$ & $1,956,727$ & $2,127,157$ & $2,297,969$ \\
\hline \multicolumn{2}{r}{ Source: BPS Provinsi Bali, 2021 } & & &
\end{tabular}

Tabel 3 persentase upah minimal kabupaten/kota Provinsi Bali 2015-2019 mengalami penurunan signifikan setiap tahunnya. Dari tahun 2015 hingga 2019 Kabupaten Badung menduduki peringkat pertama UMK tertinggi se-Provinsi Bali. Hal ini berdasarkan pasal 10 ayat 3 Permenaker Upah Minimum menyebutkan bahwa jumlah UMK harus lebih besar daripada UMP. Akibat dari diberlakukannya ketetapan kebijakan upah minimum yang akan memberikan pengurangan pada permintaan pegawai pada sektor formal. Sehingga menyebabkan lebihnya penawaran pada kepegawaian pada sektor formal, kemudian kondisi ini akan diserap oleh sektor informal yang mempunyai taraf yang tidak mengacu pada kebijakan UMR. Kemudian kondisi ini juga menyebabkan kelebihan penawaran pada sektor informal akan memberikan penurunan pada saraf upah yang diberikan. Apabila hal ini terus terjadi maka akan berimbas pada distribusi penghasilan yang akan menurun pada sektor informal (Borjas, 2008).

\section{Perkembangan Investasi Total (Investasi Asing dan Investasi Dalam Negeri) Kabupaten atau Kota (Juta Rupiah) Tahun 2014-2018}

Investasi merupakan kegiatan dalam pengeluaran investasi dalam pembelian benda atau peralatan agar dapat menambah pembuatan jasa atau barang, dengan pengharapan mendapatkan keuntungan dari hasil dan nilai tambah dari penanaman modal tersebut (Sukirno, 2010).

Tabel 4. Perkembangan Investasi Total (PMA dan PMDA) Kabupaten/Kota di Provinsi Bali (Juta Rupiah) Tahun 2014-2018

\begin{tabular}{lrrrrr}
\hline Kabupaten/Kota & \multicolumn{1}{c}{$\mathbf{2 0 1 4}$} & \multicolumn{1}{c}{$\mathbf{2 0 1 5}$} & $\mathbf{2 0 1 6}$ & \multicolumn{1}{c}{$\mathbf{2 0 1 7}$} & \multicolumn{1}{c}{$\mathbf{2 0 1 8}$} \\
\hline Jembrana & 223,570 & 191,799 & $7,065,808$ & 276,070 & $4,409,436$ \\
Tabanan & 744,363 & 445,410 & $5,298,554$ & 189,994 & 141,794 \\
Badung & $2,618,137$ & $6,329,401$ & 624,889 & $5,910,933$ & 603,994 \\
Gianyar & 542,270 & $1,217,136$ & 810,558 & 186,985 & 398,945 \\
Klungkung & 71,603 & 147,976 & 559,972 & $2,980,985$ & 65,959 \\
Bangli & 24,412 & 30,780 & 15,652 & 26,451 & 82,586 \\
Karangasem & 138,548 & 169,953 & $1,086,105$ & 393,875 & $5,337,150$ \\
Buleleng & $3,359,929$ & $1,611,311$ & 419,647 & $1,126,412$ & $2,453,691$ \\
Denpasar & $1,200,443$ & $15,728,798$ & 166,431 & $6,366,390$ & $5,138,574$ \\
\hline
\end{tabular}

Source: BPS Prov. Bali, 2021

Tabel 4 merupakan perkembangan investasi total dari gabungan investasi asing dan investasi dalam negeri dalam satuan juta rupiah kurun waktu tahun 20142018. Tahun 2014-2017 perkembangan investasi terendah diperoleh dari Kabupaten Bangli. Investasi tertinggi pada tahun 2014 diperoleh Kabupaten Buleleng dengan nominal 3,359,929 juta rupiah. Berdasarkan Teori dari Harod Domarr (Mulyadi, 2003) berpendapat yaitu, investasii bisa menambah jumlah produksi. Ini artinya bahwa semakin meningkat kapasitas produksi suatu 
perusahaan, maka semakin meningkat pula permintaan terhadap tenaga kerja, dengan asumsi fullemployment (pengerjaan penuh). Selain itu, pertumbuhan ekonomi yang meningkat terjadi juga merupakan campur tangan pemerintah yang harus aktif di dalamya (Dalamagas, 2010).

\section{Deskripsi Data Hasil Riset}

\section{a) Tingkat Kemiskinan}

Kemiskinan ialah sebuah permasalahan dalam kekurangan keuangan dan barang yang sangat kompleks yang menyebabkan sulitnya memenuhi keperluan hidup, seringkali ditemukan di berbagai negara atau wilayah. Menurut (Dartanto \& Nurkholis, 2013) jabatan dalam pekerjaan, adanya perubahan di dalam bidang pekerjaan, dan tidak stabilnya kesehatan merupakan salah satu ciri ciri dinamika dalam kemiskinan. Tingkat kemiskinan dapat ditunjukan pada Tabel 5 mengenai presentasi warga miskin berdasarkan wilayah kabupaten atau kota Provinsi Bali.

Tabel 5. Persentase Warga Miskin Berdasarkan Kabupaten atau KotaTahun 2010-2019

\begin{tabular}{|c|c|c|c|c|c|c|c|c|c|c|c|}
\hline $\begin{array}{l}\text { Kabupaten/ } \\
\text { Kota }\end{array}$ & 2010 & 2011 & 2012 & 2013 & 2014 & 2015 & 2016 & 2017 & 2018 & 2019 & $\begin{array}{l}\text { Rata } \\
\text {-rata }\end{array}$ \\
\hline Jembrana & 8.11 & 6.56 & 5.74 & 5.56 & 5.83 & 5.84 & 5.33 & 5.38 & 5.2 & 4.88 & 5.84 \\
\hline Tabanan & 6.96 & 5.62 & 4.9 & 5.21 & 5.61 & 5.52 & 5 & 4.92 & 4.46 & 4.21 & 5.24 \\
\hline Badung & 3.23 & 2.62 & 2.16 & 2.46 & 2.54 & 2.33 & 2.06 & 2.06 & 1.98 & 1.78 & 2.32 \\
\hline Gianyar & 6.68 & 5.4 & 4.69 & 4.27 & 4.57 & 4.61 & 4.44 & 4.46 & 4.19 & 3.88 & 4.71 \\
\hline Klungkung & 7.58 & 6.1 & 5.37 & 7.01 & 7.01 & 6.91 & 6.35 & 6.29 & 5.86 & 5.4 & 6.38 \\
\hline Bangli & 6.41 & 5.16 & 4.52 & 5.45 & 5.86 & 5.73 & 5.22 & 5.23 & 4.89 & 4.44 & 5.29 \\
\hline Karangasem & 7.95 & 6.43 & 5.63 & 6.88 & 7.3 & 7.44 & 6.61 & 6.55 & 6.28 & 6.25 & 6.73 \\
\hline Buleleng & 7.35 & 5.93 & 5.19 & 6.31 & 6.79 & 6.74 & 5.79 & 5.74 & 5.36 & 5.19 & 6.03 \\
\hline Denpasar & 2.21 & 1.79 & 1.52 & 2.07 & 2.21 & 2.39 & 2.15 & 2.27 & 2.24 & 2.1 & 2.09 \\
\hline Provinsi Bali & 5.67 & 4.59 & 3.95 & 4.49 & 4.76 & 4.74 & 4.25 & 4.25 & 4.01 & 3.79 & 5.84 \\
\hline
\end{tabular}

Source: (BPS, Provinsi Bali, 2020)

Tabel 5 memperlihatkan Persentase warga miskin menurut Kabupaten atau kota, dengan keadaan fluktuasi atau terjadinya kenaikan dan penurunan setiap tahun. Adapun rata rata tertinggi persentase warga miskin terjadi pada Kabupaten Karangasem dengan persentase 6,73 persen. Rata rata persentase terendah dapat diperoleh dari Kota Denpasar dengan persentase 2,06 persen.

\section{b) Tingkat Pendidikan}

Tingkat pendidikan bisa dipakai menjadi sebuah tanda untuk mencari tahu sejahteraan warga. Di mana jenjang pendidikan yang baik akan membuat seseorang lebih baik. Salah satu indikator tingkat pendidikan ditunjukan pada Tabel 6 mengenai rata-rata lama sekolah:

Tabel 6. Rata-Rata Lama Sekolah Tahun 2010-2019 pada Kabupaten/Kota di Provinsi Bali (Tahun)

\begin{tabular}{lccccccccccc}
\hline $\begin{array}{l}\text { Kabupaten/ } \\
\text { Kota }\end{array}$ & $\mathbf{2 0 1 0}$ & $\mathbf{2 0 1 1}$ & $\mathbf{2 0 1 2}$ & $\mathbf{2 0 1 3}$ & $\mathbf{2 0 1 4}$ & $\mathbf{2 0 1 5}$ & $\mathbf{2 0 1 6}$ & $\mathbf{2 0 1 7}$ & $\mathbf{2 0 1 8}$ & $\mathbf{2 0 1 9}$ & $\begin{array}{l}\text { Rata- } \\
\text { rata }\end{array}$ \\
\hline Jembrana & 7.05 & 7.23 & 7.25 & 7.27 & 7.3 & 7.54 & 7.5 & 7.6 & 7.95 & 8.22 & 7.50 \\
Tabanan & 7.6 & 7.68 & 7.76 & 7.83 & 7.91 & 8.07 & 8.1 & 8.4 & 8.64 & 8.87 & 8.08 \\
Badung & 8.8 & 8.96 & 9.07 & 9.18 & 9.29 & 9.44 & 9.9 & 9.9 & 10.0 & 10.3 & 9.50 \\
Gianyar & 7.5 & 7.73 & 7.99 & 8.24 & 8.28 & 8.49 & 8.8 & 8.8 & 8.92 & 8.94 & 8.38
\end{tabular}




\begin{tabular}{lccccccccccc} 
Klungkung & 6.6 & 6.68 & 6.81 & 6.88 & 6.9 & 6.98 & 7.0 & 7.4 & 7.75 & 8.12 & 7.12 \\
Bangli & 5.93 & 5.97 & 6.01 & 6.35 & 6.38 & 6.41 & 6.4 & 6.8 & 7.13 & 7.16 & 6.45 \\
Karangasem & 4.55 & 4.6 & 5.22 & 5.34 & 5.39 & 5.42 & 5.4 & 5.5 & 5.97 & 6.31 & 5.38 \\
Buleleng & 6.23 & 6.39 & 6.51 & 6.63 & 6.66 & 6.77 & 6.8 & 7.0 & 7.04 & 7.08 & 6.71 \\
Denpasar & 10.4 & 10.59 & 10.8 & 10.9 & 10.96 & 11.0 & 11. & 11.1 & 11.1 & 11.2 & 10.93 \\
\hline Provinsi Bali & 7.74 & 7.77 & 8.05 & 8.1 & 8.11 & 8.26 & 8.3 & 8.5 & 8.65 & 8.84 & 8.243
\end{tabular}

Source: (BPS, Provinsi Bali, 2020)

Tabel 6 menunjukan kesenjangan dalam tingkat pendidikan di Bali. Ratarata lama sekolah dari tahun 2010-2019 di kabupaten atau kota Provinsi Bali menghasilkan rata-rata pendidikan 8.243 tahun. Namun, masih terdapat beberapa kabupaten yang mempunyai nilai tingkat pendidikan di bawah ratarata Provinsi Bali. Karangasem merupakan kabupaten dengan nilai rata-rata terendah, yaitu 5.38 tahun.

\section{c) Tingkat kesehatan}

Kesehatan ialah sebuah aspek penting dalam mendukung kesuksesan pada pembangunan khususnya untuk menaikkan kesejahteraan sosial. Hal tersebut ditandai dengan angka harapan hidup atau AHH yaitu rerata hidup seseorang dalam setahun, sampai dengan tahun tertentu atau $\mathrm{x}$, dalam kondisi mortalitas yang ada di disekitarnya. (BPS 2020) Semakin tinggi AHH, maka semakin menampakan derajat kesehatan, peningkatan kehidupan dan kesejahteraan masyarakat di suatu wilayah. Berikut Tabel 5 mengenai angka harapan hidup tahun 2010-2019.

Tabel 7. Angka Harapan Hidup Tahun 2010-2019 pada Kabupaten/Kota di Provinsi Bali (Tahun)

\begin{tabular}{lrllllllllll}
\hline $\begin{array}{l}\text { Kabupaten/Ko } \\
\text { ta }\end{array}$ & 2010 & 2011 & 2012 & 2013 & 2014 & 2015 & 2016 & 2017 & 2018 & 2019 & $\begin{array}{c}\text { Rata - } \\
\text { rata }\end{array}$ \\
\hline Jembrana & 70.75 & 70.92 & 71.09 & 71.26 & 71.39 & 71.43 & 71.57 & 71.7 & 71.91 & 72.21 & 71.42 \\
Tabanan & 72.02 & 72.18 & 72.35 & 72.52 & 72.64 & 72.74 & 72.89 & 73.03 & 73.23 & 73.53 & 72.71 \\
Badung & 73.77 & 73.91 & 74.05 & 74.19 & 74.3 & 74.31 & 74.42 & 74.53 & 74.71 & 74.99 & 74.31 \\
Gianyar & 72.31 & 72.43 & 72.57 & 72.71 & 72.78 & 72.84 & 72.95 & 73.06 & 73.26 & 73.56 & 72.84 \\
Klungkung & 69.26 & 69.45 & 69.66 & 69.84 & 69.91 & 70.11 & 70.28 & 70.45 & 70.7 & 71.06 & 70.07 \\
Bangli & 68.8 & 68.98 & 69.18 & 69.36 & 69.44 & 69.54 & 69.69 & 69.83 & 70.05 & 70.37 & 69.52 \\
Karangasem & 68.56 & 68.76 & 68.96 & 69.12 & 69.18 & 69.48 & 69.66 & 69.85 & 70.05 & 70.35 & 69.39 \\
Buleleng & 70.06 & 70.23 & 70.41 & 70.58 & 70.71 & 70.81 & 70.97 & 71.14 & 71.36 & 71.68 & 70.79 \\
Denpasar & 73.24 & 73.34 & 73.44 & 73.56 & 73.71 & 73.91 & 74.04 & 74.17 & 74.38 & 74.68 & 73.84 \\
\hline Provinsi Bali & 70.61 & 70.78 & 70.94 & 71.11 & 71.2 & 71.35 & 71.41 & 71.46 & 71.68 & 71.99 & 71.25 \\
\hline Source: (BPS & Provins & & & & & & & & & &
\end{tabular}

Source: (BPS, Provinsi Bali, 2020)

Dapat dilihat pada Tabel 7, bahwa setiap tahun angka harapan hidup pada kota yang diteliti mengalami fluktuasi. AHH rata rata tertinggi dari tahun 2010-2019 di dapatkan oleh Kabupaten Badung yaitu 74.31 tahun, angka harapan hidup di Kabupaten Badung menunjukkan keberhasilan pembangunan kesehatan tertinggi di kabupaten atau kota Provinsi Bali. Sedangkan, AHH terendah dari tahun 2010-2019 didapatkan oleh Kabupaten Karangasem yaitu 69.39 tahun. 


\section{d) Tingkat Pengangguran Terbuka}

Penganggurann terbuka adalah Sebuah kondisi seseorang termasuk pada angkatan kerja namun belum mendapatkan suatu pekerjaan (Sukirno, 1997). Salah satu indikator untuk menghitung tingkat pengangguran terbuka digunakan yaitu persentase tingkat pengangguran terbuka tahun 2010-2019 pada kabupaten /kota Prov. Bali.

Tabel 8. Persentase Tingkat Pengangguran Terbuka Tahun 2010-2019 pada Kabupaten/Kota di Provinsi Bali

\begin{tabular}{lrrrrrrrrrr}
\hline $\begin{array}{l}\text { Kabupaten/ } \\
\text { Kota }\end{array}$ & 2010 & 2011 & 2012 & 2013 & 2014 & 2015 & 2016 & 2017 & 2018 & 2019 \\
\hline Jembrana & 2.54 & 3.53 & 1.97 & 3.46 & 2.95 & 1.59 & 2.38 & 0.67 & 1.38 & 1.42 \\
Tabanan & 1.07 & 2.8 & 2.18 & 0.8 & 2.25 & 1.73 & 1.75 & 1.79 & 1.43 & 1.28 \\
Badung & 1.25 & 2.28 & 1.67 & 0.8 & 0.48 & 0.34 & 1.10 & 0.48 & 0.44 & 0.38 \\
Gianyar & 2.36 & 2.11 & 1.81 & 2.23 & 1.43 & 1.93 & 1.43 & 1.02 & 1.6 & 1.42 \\
Klungkung & 3.59 & 2.35 & 2.09 & 2.08 & 1.94 & 1.39 & 1.86 & 0.94 & 1.41 & 1.54 \\
Bangli & 0.65 & 0.81 & 0.9 & 0.77 & 0.67 & 1.72 & 1.02 & 0.48 & 0.8 & 0.72 \\
Karangasem & 2.82 & 2.7 & 1.31 & 1.39 & 2.06 & 2.15 & 1.77 & 0.72 & 0.99 & 0.60 \\
Buleleng & 3.26 & 3.28 & 3.13 & 2.15 & 2.74 & 2.04 & 2.42 & 2.41 & 1.84 & 3.02 \\
Denpasar & 6.57 & 4.56 & 2.57 & 2.72 & 2.32 & 3.54 & 2.63 & 2.63 & 1.82 & 2.22 \\
\hline Provinsi & 3.06 & 2.95 & 2.1 & 1.83 & 1.9 & 1.99 & 1.89 & 1.48 & 1.37 & 1.52 \\
Bali & & & & & & & & & &
\end{tabular}

Source: (BPS, Provinsi Bali, 2020)

Tabel 8 menunjukan persentase jenjang pengangguran terbuka tahun 20102019 di Kab/Kota Prov. Bali. Rata rata persentase pengangguran di Bali mengalami penurunan yang signifikan setiap tahunnya. Persentase pengangguran terendah dari tahun 2010-2019 dapat diperoleh Kabupaten Badung yaitu 0.34 pada tahun 2015. Sedangkan persentase pengangguran tertinggi dari tahun 2010-2019 diperoleh Kabupaten Klungkung dengan persentase 3.59 pada tahun 2010.

\section{B. Pembahasan}

Uji Spesifikasi Model

1) Uji Chow

Tabel 9. Uji Chow

\begin{tabular}{lrrrr} 
Effects Test & Statistic & & d.f. & Prob. \\
\cline { 1 - 1 } & & & \\
Cross-section F & 12.973668 & & $(8,78)$ & 0.0000 \\
Cross-section Chi-square & 76.152575 & 8 & 0.0000
\end{tabular}

Source: hasil olahan eviews 2021

Pada Tabel 9 Uji Chow, didapat $\mathrm{F}_{\text {hitung }}=12.973668$, lalu untuk mendapat angka nilai $\mathrm{F}_{\text {tabel }}$, nilai d.f $=(8,78)$, taraf signifikasi alpa $5 \%$. Kemudian didapat angka $F_{\text {tabel }}$ nya yaitu 2.06. Hasil uji yang didapatkan memperoleh $F_{\text {hitung }}$ lebih besar dari $\mathrm{F}_{\text {tabel, }}$, jadi model yang terpilih yaitu FEM. 
2) Uji Hausman

Tabel 10. Uji Chow

\begin{tabular}{lrrr} 
Test Summary & $\begin{array}{l}\text { Chi-Sq. } \\
\text { Statistic }\end{array}$ & Chi-Sq. d.f. & Prob. \\
\hline Cross-section random & 3.830023 & 3 & 0.2804
\end{tabular}

Source: hasil olahan eviews 2021

Menurut Tabel 10 Uji Hausman, maka diperoleh angka Prob. 0.2804. Taraf signifikasi alpa 5\% yaitu 0.05 , jadi $0.2804>0.05$. Maka yang terbaik digunakan Bentuk Random.

Hasil Analisa Regresi Linear Berganda

Tabel 11. Hasi Uji Analisis Regresi Linear Berganda Bentuk Random Effect

\begin{tabular}{crrrr} 
Variabel & Coefficient & Std. Error & t-Statistic & Prob. \\
\hline & & & & \\
\hline C & 16.34608 & 7.864211 & 2.078540 & 0.0406 \\
X1 & -0.855154 & 0.135498 & -6.311174 & 0.0000 \\
X2 & -0.069513 & 0.122777 & -0.566177 & 0.5727 \\
X3 & 0.154348 & 0.076863 & 2.008079 & 0.0478
\end{tabular}

Source: hasil olahan eviews 2021.

Menurut hasil analisa pada Tabel 11, mendapat persamaan model regresi seperti dibawah ini:

$$
Y=16.346-0.855 X_{1}-0.069 X_{2}+0.154 X_{3}
$$

Sebelum persamaan itu digunakan, maka dilaksanakan pengujian menggunakan asumsi klasik.

\section{Uji Asumsi Klasik}

\section{1). Uji Normalitas}
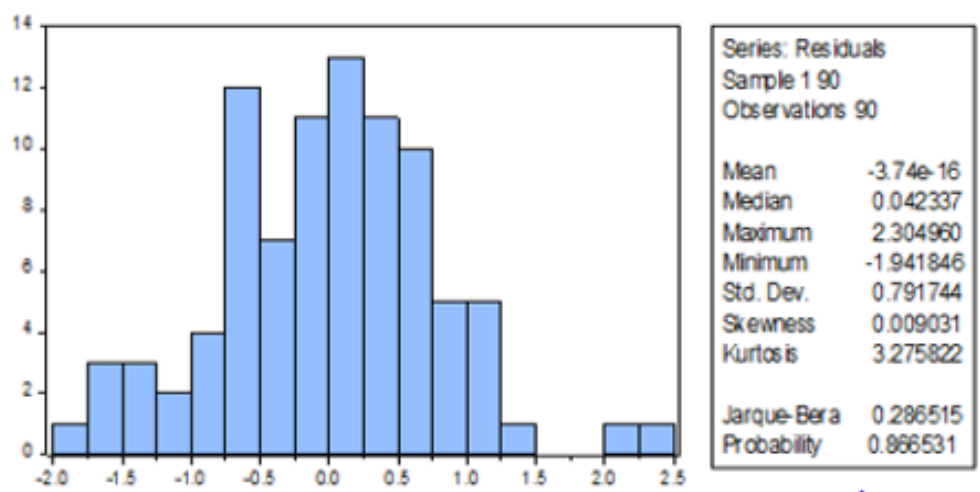

Source: Hasil olah di Eviews 10, 2021

Pengaruh Tingkat Pendidikan, Tingkat Kesehatan, dan Pengangguran Terbuka Terhadap 


\section{Gambar 4 Hasil Uji Normalitas}

Dapat dilihat pada probability pada Gambar 4 menunjukan nilai $0.866>$ 0.05 , ini menandakan residual berdistribusi normal.

\section{3) Uji Multikolinieritas}

\section{Tabel 12 Hasil Uji Multikolinearitas}

Variance Inflation Factors

Date: 03/16/21 Time: 22:54

Sample: 190

Included observations: 90

\begin{tabular}{cccc}
\hline & $\begin{array}{c}\text { Coefficien } \\
\mathbf{t} \\
\text { Variance }\end{array}$ & $\begin{array}{c}\text { Uncentere } \\
\mathbf{d} \\
\text { VIF }\end{array}$ & $\begin{array}{c}\text { Centered } \\
\text { VIF }\end{array}$ \\
\hline & & & \\
C & 61.57368 & 8542.336 & NA \\
X1 & 0.018263 & 160.5206 & 6.800195 \\
X2 & 0.014976 & 10675.99 & 6.749800 \\
X3 & 0.007345 & 4.443874 & 1.068329 \\
& & & \\
\hline
\end{tabular}

Source : Hasil olahan Eviews 10, 2021

Menurut Tabel 12 memperlihatkan bahwa setiap variabel bebas mempunyai angka Centered VIF $<10$, jadi bisa dikatakan tidak terdapat gejala yang mengandung multikolinieritas.

\section{4). Uji Heteroskedastisitas}

\section{Tabel 13 Hasil Uji Heteroskedastisitas} Heteroskedasticity Test: Glejser

$\begin{array}{llll}\text { F-statistic } & 0.743752 & \text { Prob. F(3,86) } & 0.5289 \\ \text { Obs*R-squared } & 2.275986 & \text { Prob. Chi-Square(3) } & 0.5171 \\ \text { Scaled explained SS } & 2.266111 & \text { Prob. Chi-Square(3) } & 0.5190\end{array}$

Source: Hasil dari olah data Eviews 10, 2021

Menurut Tabel 13 menjelaskan bahwa Prob. F $(3,86)$ memperoleh nilai sig 0.5289 yang berarti nilai $0.5289>0.05$ ini menandakan model tidak ada gejala heteroskedastisitas.

\section{5). Uji Koefisien Regresi secara Simultan}

Merujuk Tabel 10, dengan tingkat nyata $\alpha=0,05$ atau tingkat keyakinan 95\% dengan derajat bebas $\mathrm{df}_{1}=8 \mathrm{dan}_{\mathrm{df}_{2}}=78$. Maka diperoleh nilai $\mathrm{F}_{\text {tabel }}=2.06$. Dan nilai $\mathrm{F}_{\text {hitung }}=12.973668>\mathrm{F}_{\text {tabel }}=2.06$, jadi dapat disimpulkan $\mathrm{H}_{0}$ ditolak, ini 
berarti secara simultan variabel bebas berpengaruh signifikan terhadap variabel terikat.

\section{6). Uji Koefisien Regresi secara Parsial}

Merujuk Tabel 11, diperoleh hasil bahwa nilai $t_{\text {hitung }}-6.311 \leq-1.663 \mathrm{t}_{\text {tabel }}$ sesuai kriteria pengujian, maka $\mathrm{H}_{0}$ ditolak, nilai probnya $0.000<0.05$, yang mempunyai arti secara parsial pendidikan berpengaruh negatif dan sig terhadap kemiskinan. Hasil koefisien variabel $\left(\mathrm{X}_{1}\right)$ terhadap $(\mathrm{Y})$ yaitu -0.855 menyimpulkan, jika tingkat pendidikan bertambah sebesar 1 tahun menjadikan kemiskinan mendapatkan penurunan senilai 0.855 persen. Asumsi jika variabel bebas $\left(\mathrm{X}_{2}\right)$ dan $\left(\mathrm{X}_{3}\right)$ konstan.

Pengaruh tingkat kesehatan terhadap kemiskinan memperoleh nilai $t_{\text {hitung }}$ $0.566>-1.663 \mathrm{t}_{\text {tabel, }}$, sesuai kriteria pengujian, maka $\mathrm{H}_{0}$ diterima, serta berdasarkan nilai probnya $0.572>0.05$ yang berarti secara parsial tingkat kesehatan berpengaruh negatif namun tidak sig. Ketika kesehatan dengan indikator angka harapan hidup mengalami peningkatan, maka tingkat kemiskinan mengalami penurunan namun tidak signifikan penurunannya, begitu juga sebaliknya.

Pengaruh tingkat pengangguran terbuka terhadap kemiskinan memperoleh nilai $\mathrm{t}_{\text {hitung }} 2.008>1.663 \mathrm{t}_{\text {tabel }}$, maka $\mathrm{H}_{0}$ ditolak yang berarti tingkat pengangguran terbuka secara parsial berpengaruh positif dan sig. Hasil dari koefisien variabel $\left(\mathrm{X}_{3}\right)$ terhadap $(\mathrm{Y})=0.154$, menyimpulkan, jika variable $\left(\mathrm{X}_{3}\right)$ bertambah sebesar 1 persen menjadikan (Y) juga meningkat 0.154 persen dengan mengasumsikan variabel tingkat pendidikan serta tingkat kesehatan konstan.

\section{Pengaruh Variabel Dominan}

Untuk mengetahui variabel mana yang dominan maka dipakai uji standardized coefficient beta dengan mencari standardized coefficient beta $(\beta)$ tertinggi setiap variabel (Gujarati D. , 1997).

Tabel 12 Pengaruh variabel Dominan:

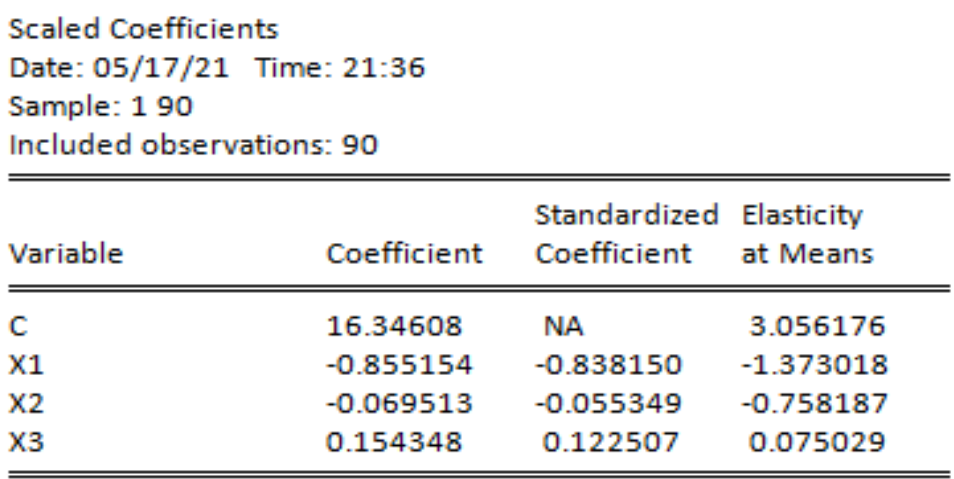

Source: Hasil olah data Eviews 10, 2021

Dengan melihat Tabel 12, nilai standardized coefficient dari tiap variabel independen diatas, Sehingga didapat variabel bebas yang mempunyai pengaruh paling tinggai yakni vaiabel bebas tingkat pendidikan $\left(\mathrm{X}_{1}\right)$, karena nilai $\beta$ nya lebih tinggi dibandingan variabel lain, yaitu 0.838 . Hal ini terjadi karena semakin luas wawasan didukung oleh tingginya pendidikan yang didapat. Sehingga mempermudah mempelajari dan cepat menerima hal hal baru. Meningkatnya tingkat pendidikan akan meningkatkan produktivitas juga. 


\section{Pembahasan Riset}

Menurut hasil yang diperoleh dari riset ini, kualitas pendidikan mempengaruhi kemiskinan yang ada di Bali, intepretasinya yaitu jika kualitas pendidikan mengalami kenaikan, maka yang terjadi yaitu kemiskinan akan mengalami penurunan. Studi empiris yang mendukung dilihat dari peneliti seperti (Wahyu \& et, 2018) menerangkan hasil yang sama namun berlokasi di kabupaten atau kota Provinsi Jawa Timur. Teori Human Capital yaitu modal manusia yang ditemukan oleh (Becker, 1993), teori ini mengajarkan bahwa pendidikan bisa meningkatkan keahlian atau skill yang bisa meningkatkan produktivitas. Teori ini juga meyatakan apabila karyawan/pekerja mempunyai produktivitas yang baik, maka tingkat pendapatan yang diberikan dari perusahaan juga akan meningkat.

Terdapat teori lingkaran setan yang bisa mempengaruhi tingkat kemiskinan. Apabila tingkat pendidikan yang ditempuh rendah, bisa mempengaruhi produktivitas SDM yang rendah, dan mengakibatkan mendapatkan upah yang rendah pula, sehingga bisa menyebabkan meningkatnya tingkat kemiskinan. Maka dari itu, sangat penting pemerintah untuk mewajibkan biaya pendidikan minimal 20\% dari APBD, guna memperbaiki kualitas sumber daya manusianya, agar kedepannya bisa memutus tali lingkaran setan.

Menurut hasil riset tingkat kesehatan tidak mempunyai pengaruh terhadap kemiskinan di Bali. Didukung dari riset yang dilaksanakan Faisal (Faisal, 2013), menyimpulkan bahwa tingkat kesehatan tidak mempunyai pengaruh terhadap kemiskinan dan tingkat produktivitas di Provinsi Kalimantan Barat. Riset juga didukung oleh Wongdesmiwati, yang menyimpulkan bahwa variabel angka harapan hidup tidak signifikan berpengaruh terhadap warga miskin (Wongdesmiwati, 2009). Studi empiris lain (Fitri \& Kaluge, 2017) bahwa variabel biaya pemerintahan di sektor tingkat kesehatan berdampak positif dan tidak signifikan. Karena tidak sejalannya penambahan kesehatan warga dengan kuantitas kesempatan kerja baru.

Berdasarkan data yang diperoleh dari BPS mengenai angka harapan hidup (AHH) tahun 2010-2019, beberapa kabupaten atau kota memperoleh rata rata $\mathrm{AHH}$ diatas rata rata Provinsi Bali. Hal ini mengindikasikan kualitas kesehatan masyarakat Kabupaten/Kota di Provinsi Bali terbilang bagus atau sehat. Warga yang memiliki kesehatan dapat juga tidak memiliki pekerjaan dan tidak mempunyai pengaruh dalam pengurangan kemiskinan. Selain itu juga, data yang diperoleh dari BPS mengenai persentase biaya kesehatan tahun 2015-2019 di Provinsi Bali juga menyatakan bahwa biaya kesehatan sudah menyentuh alokasi biaya minimal bahkan diatas 10 persen dari tahun 2015-2019, berdasarkan UU Kesehatan No 36 Tahun 2006.

Hasil riset juga menunjukkan bahwa tingkat pengangguran terbuka mempengaruhi tingkat kemiskinan, yang didukung oleh beberapa riset sebelumnya. Studi empiris dilakukan oleh (Adi \& Arka, 2018), (Malat \& Jeffrey , 2013), (Aristina, Kembar , \& Darsana, 2017), (Hu \& Giuliano, 2017), (Wirawan \& Arka, 2015), (Williams, 2008), (Yanthi \& Marheni, 2015), menyimpulkan bahwa pengangguran terbuka mempunyai hasil yang sama dengan penelitian ini yaitu mempengaruhi tingkat kemiskinan. Semakin bertambahnya pengangguran maka akan mengakibatkan adanya pertambahan penduduk yang tidak produktif, sehingga hal tersebut tidak dapat mencukupi keperluan kehidupannya, ketika keperluannya tidak tercukupi dapat mengakibatkan tergoncangnya stabilitas dalam politik negara, selain itu juga dapat mengakibatkan bertambahnya angka kejahatan (Azeng \& Thierry, 1991-2009). Berdasarkan Teori dari Harod Domarr (Mulyadi, 2003) berpendapat yaitu, Investasii bisa menambah kapasitas produksi. Ini artinya bahwa semakin meningkat kapasitas produksi suatu perusahaan, maka semakin meningkat pula permintaan terhadap tenaga kerja, dengan asumsi fullemployment (pengerjaan penuh). Ini terjadi karena penanaman modal ialah aspek yang menentukan penambahan produksi, dan tenaga kerja merupakan salah satu aspek tersebut. 


\section{KESIMPULAN}

Secara simultan tingkat pendidikan, tingkat kesehatan, serta tingkat pengangguran terbuka berpengaruh terhadap tingkat kemiskinan kab/kota di Provinsi Bali. Secara parsial tingkat pendidikan berpengaruh negatif dan signifikan terhadap tingkat kemiskinan kabupaten/kota di Provinsi Bali. Secara parsial tingkat kesehatan berpengaruh negatif dan tidak signifkan terhadap tingkat kemiskinan kabupaten/kota di Provinsi Bali. Secara parsial tingkat pengangguran terbuka berpengaruh positif dan signifikan terhadap tingkat kemiskinan kabupaten/kota di Provinsi Bali. Variabel yang memiliki pengaruh dominan terhadap tingkat kemiskinan, yaitu tingkat pendidikan.Penutup merupakan simpulan dari hasil penelitian yang telah dilaksanakan dan merupakan jawaban dari rumusan masalah. Simpulan diselaraskan dengan rumusan masalah dan tujuan penelitian. Dalam hal simpulan lebih dari satu, maka dituliskan menggunakan penomoran angka dan bukan menggunakan bullet. Dalam bagian penutup ini juga dapat ditambahkan prospek pengembangan dari hasil penelitian dan aplikasi lebih jauh yang menjadi prospek kajian berikutnya.

\section{BIBLIOGRAFI}

Adi, P., \& Arka, S. (2018). Analisis tingkat pengangguran terbuka, kesempatan kerja, dan tingkat pendidikan terhadap tingkat kemiskinan di kabupaten/kota provinsi Bali. E-Jurnal EP Unud, 416-444.

Aristina, I., Kembar , M., \& Darsana, I. (2017). Pengaruh tingkat pendidikan, pengangguranm dan pertumbuhan ekonomi terhadap kemiskinan di Provinsi Bali. Jurnal Ekonomi Kuantitatif Terapan, 677-704.

Azeng, T., \& Thierry, U. (1991-2009). Youth Unemployment, Education and Political Iinstability. Evidence from selected developing countries, 200.

Becker. (1993). Human Capital. A Theoretical and Empirical Analysis with Special Reference to Education ( $3 r d$ ed). London: The University of Chicago Press.

Borjas, G. (2008). Labor Economics. Newyork: McGraw-Hill.

BPS. (2020, September 4). Provinsi Bali. Retrieved from https://bali.bps.go.id: https://bali.bps.go.id/dynamictable/2018/02/27/252/jumlah-pengangguran-diprovinsi-bali-menurut-kabupaten-kota-2007-2015.html

BPS. (2020, September 4). Provinsi Bali. Retrieved from https://bali.bps.go.id: https://bali.bps.go.id/subject/23/kemiskinan-danketimpangan.html\#subjekViewTab3

BPS. (2020, September 4). Provinsi Bali. Retrieved from https://bali.bps.go.id: https://bali.bps.go.id/dynamictable/2018/02/27/252/jumlah-pengangguran-diprovinsi-bali-menurut-kabupaten-kota-2007-2015.html

BPS. (2020, September 4). Provinsi Bali. Retrieved from https://Bali.bps.go.id: https://bali.bps.go.id/subject/30/kesehatan.html\#subjctviewtab3

Dalamagas, B. (2010). Public Sector and economic growth: The greek experience. Bulletin of Indonesian Economic Studies 2000, 277-288.

Dariwardani, N. (2014). Analisis Dinamika Kemiskinan (Poverty Dynamics) di Bali Berdasarkan Data Susenas Panel 2008. Jurnal Ekonomi Kuantitatif Terapan, vol. 7, no. 1 .

Dartanto, T., \& Nurkholis. (2013). The determinants of poverty dynamics in Indonesia: Evidence from Panel Data. Bulletin of Indonesian economic studies vol.49 No.1, 61-84.

Dollar, D., \& Aart Kraay. (2002). Growth is good for the poor. Journal Of Economic Growth, 1-14. 
Ewubare, D., Ogbuagu, \& Regina, A. (2017). Unemployment rate, gender inequality and economic growt in Nigeria: "A short-run Impact Analysis". Global Journal of Human Resouce Management, 12-43.

Faisal, H. (2013). Pengaruh tingkat pendidikan, kesehatan terhadap produktivitas dan jumlah penduduk miskin di Provinsi Kalimantan Barat. Program Magister Ilmu Ekonomi Universitas Tanjung Pura Pontianak.

Fitri, \& Kaluge. (2017). Analisis pengaruh pengeluaran pemerintah sektor pendidikan dan kesehatan terhadap kemiskinan di Jawa Timur. Jurnal Ekonomi, 130-136.

Gujarati, D. (1997). Ekonometrika Dasar. Jakarta: Erlangga.

Hu, L., \& Giuliano, G. (2017). Poverty concentration, job access, and employment outcomes. Journal Bulletion of Indonesia Studies, 39(1) pp: 1-16.

Kuncoro, M. (2004). Otonomi dan pembangunan daerah: reformasi, perencanaan, strategi dan peluang. Jakarta: Erlangga.

Lim, H.-E. (2011). The determinants of individual unemployment duration: The case of Malaysian Graduates. Journal of global management, pp.184203.

Mahmood, \& et al. (2014). Determinants of unemployment in Pakistan: A Statistical Study. International Journal Of Asian Social Science, 4(12) Pp 11631175.

Malat, J., \& Jeffrey , T. M. (2013). Country level unemployment change and trends in self-rated health. Journal Bulletin of Indonesian Economic Studies, 46(1) pp: 2546.

Manning, C., \& Junankar. (1998). Choosy Youth Or Unwanted Youth? A survey of unemployment. Bulletin of Indonesia Economic Studies, 34(1), PP: 55-95.

Meidani, A. (2011). The dynamic effect of unemployment rate on per capital real GDP in Iran. International Journal Of Economics and Finance, 3 (05), pp 170-177.

Mulyadi, S. (2003). Ekonomi Sumber Daya Manusia dalam perspektif pembangunan. Jakarta: Qudratullah.

Seran, S. (2017). Pendidikan, Pengangguran, dan Pertumbuhan Ekonomi terhadap Kemiskinan Penduduk. Jurnal Ekonomi Kuantitatif Terapan, vol. 10, no. 1.

Shah, A., Shanzadi, U., \& Jean, J. (2012). Demand for generic competences in the Labour Market: Reliability of workers perception. International Journal of Economics and Finance, pp: 227-240.

Sri Budhi, M. K. (2013). Analisis Faktor-faktor yang Berpengaruh terhadap Pengentasan Kemiskinan di Bali: Analisis FEM Data Panel. Jurnal Ekonomi Kuantitatif Terapan, vol. 6, no. 1.

Sugiyono. (2013). Metode penelitian kuantitatif kualitatif dan R\&D. Bandung: Alfabeta.

Sukirno, S. (2010). Pengantar Teori Makro Ekonomi. Jakarta: PT. Raja Grafindo Persada.

Tisnawati, \& Shabrina, R. (2014). Analisis Pengaruh Jumlah Tanggungan Keluarga, Umur, Pendidikan dan Status Pekerjaan terhadap Pendapatan Keluarga Wanita Single Parent. Jurnal Ekonomi Kuantitatif Terapan, vol. 7, no. 2.

Vincent, B. (2009). The concept "poverty" towards understanding in the context of developing countries "poverty" qua povety. Journal of Sustainable Development, $2(2)$.

Wahyu, E., \& et. (2018). Pengaruh pendidikan, pendapatan perkapita dan jumlah penduduk terhadap kemiskinan di Provinsi Jawa Timur. Jurnal Ilmu Ekonomi.

Wardhana, D., Ihle, R., \& Heijman, W. (2017). Agro cluster and rural poverty: A Spatial erspective for West Java. Bulletin Of Indonesian Economic Studies, Vol 53, No 2.

Williams, D. (2008). Poverty and unemployment traps and trappings. Journal Bulletin of Indonesia Studies, 8 (2), pp: 96-107.

Williamson, D. (2001). The role of the health sector in addresinh povety. Canadian Journal of Public Health, 92(3), pp 178-183.

Wirawan, N. (2017). Cara mudah memahami statistika. Denpasar: Keraras Emas. 
Wirawan, T., \& Arka, S. (2015). Analisa pengaruh pendidikan, Pdrb per Kapita dan Tingkat pengangguran terhadap jumlah penduduk miskin di Provinsi Bali. Jurnal Ekonomi Kuantitatif Terapan, vol.4 no 5.

Wongdesmiwati. (2009). Pertumbuhan ekonomi dan pengentasan kemiskinan di Indonesia Tahun 1990-2004: Analisis Ekonometrika. Jurnal Ekonomi Pembangunan.

Yanthi, P., \& Marheni. (2015). Pengaruh pendidikan, tingkat upah dan pengangguran terhadap tingkat kemiskinan di Kabupaten/Kota Provinsi Bali. Jurnal Kependudukan dan Pengembangan Sumber Daya Manusia.

Yuta, Ropika, \& Suhartini, A. M. (2014). Keterkaitan Lembaga Keuangan Mikro (LKM), Usaha Mikro dan Kecil (UMK) Serta Kemiskinan di Indonesia Tahun 2012. Jurnal Ekonomi Kuantitatif Terapan, vol. 7, no. 2.

(C) 2021 by the authors. Submitted for possible open access publication under the terms and conditions of the Creative Commons Attribution (CC BY SA)

license (https://creativecommons.org/licenses/by-sa/4.0/). 